\title{
De marginale med Huntingtons sykdom
}

\author{
Når en arvelig sykdom kommer som et sjokk på den den rammer, når man knapt har hørt om sykdommen \\ før og, ikke minst, når diagnosen innebærer det verste av det verste - hva gjør man da?
}

Dette innlegget kommer fra en av de sjeldneste av de sjeldne. Vi er 300 med Huntingtons sykdom i Norge totalt. Sykdommen starter typisk i 40-årene, og den går typisk i familier. Fordi jeg var 67 år da jeg fikk diagnosen i fjor og heller ikke hadde noen i familien med dette, trodde jeg at jeg umulig kunne bli rammet. Men jo. Sporadisk, ukjent hereditet. Jeg hadde ikke kjent meg syk og hadde vært i full jobb frem til jeg var 66 år. Det var familien som reagerte mest på choreaen.

Til for et halvt år siden hadde jeg ikke sett noen andre enn meg selv med dette. Og ja, jeg må innrømme at måten vi går på er pussig og skjønner hvorfor folk rundt meg holder pusten - de tror jeg er i ferd med å falle. Men som en som tilfeldigvis gikk nær meg sa: «Jeg ser du kan fote deg i terrenget.» Det var så vakkert sagt, rent poetisk. Jeg sparer på dette uttrykket i møte med «vedlikehold av funksjon», som det heter i omsorgssektoren. Mange virker livredde for at vi skal innbille oss at vi blir bedre av noe de gjør for oss, det være seg fysioterapeuter eller logopeder.

Forverring, forverring er det virkelige spøkelset. Det er rent ut sagt deprimerende å lese om sykdommen, alle de grusomme utslagene den kan ha - ikke minst personlighetsforandringer. Jeg har lest mye, og jeg er en kritisk leser også, så jeg sorterer og tar ikke inn alt. Det har vært en lettelse å google «late onset» og lese at choreaen da ofte er mer moderat, den kognitive svikten mindre og at sykdomsutviklingen går langsommere. Jeg kan heller ikke se at denne personlighetsforandringen har skjedd hos meg.

Folk blir ofte så alvorlige rundt meg - det gjelder personalet på sykehus og i omsorgssektoren så vel som venner og fjernere bekjentskaper som jeg forteller om diagnosen. Og det er selvfølgelig en alvorlig diagnose, men siden den er så sjelden, er det få

\section{«Det er slett ikke mørkt på min innside»}

som har møtt noen med den. Mange har ikke peiling, selvfølgelig, meg selv inkludert. Før. Det tunge alvoret blir ekstra sterkt siden jeg som regel er i godt humør og kan spøke og le. Det er slett ikke mørkt på min innside.

Etter diagnosen i fjor var jeg på et habiliteringsopphold på Vikersund. Der brukte jeg tiden til å skrive meg igjennom sjokk, sorg og sinne over diagnosen og å forsøke å skape mening. Jeg vil trekke frem hvordan Susan Sontags Sykdom som metafor (1) ble en god kategorisering for meg. Hun sier at vi som mennesker fødes inn $i$ to verdener, den friske og den syke. Noen av oss får leve $i$ den friske verdenen lenge, og da tenker vi ikke på at vi uvegerlig blir syke til slutt. Andre opplever sykdom tidligere, og da er det lett å bli oppslukt i den syke verdenen. Men deler av oss har fortsatt bolig i den friske verdenen. Uansett hvordan denne sykdommen vil herje med meg, vil deler av meg være friske Tove.

Vi mennesker er forskjellige i hvordan vi søker fellesskap med andre med samme diagnose. Jeg vegrer meg litt for det. Min kontakt med sykehusverdenen før jeg fikk Huntingtons sykdom har begrenset seg til to hofteproteser med påfølgende rehabilitering på et kursted. Og nei, det var ikke der at jeg endelig følte fellesskap og behov for videre kontakt med mine medmennesker, tvert imot var jeg overlykkelig over å slippe hjem.

Med min Huntingtons sykdom-diagnose er jeg dagpasient på et sykehjem to ganger i uken, og det er en balansegang mellom å bli for oppslukt av sykdommen på den ene siden og å ha glede av samværet med medpasientene, som jeg etter hvert kjenner godt, på den andre. I tillegg ytrer denne sykdommen seg individuelt, så det er ikke alltid like godt grunnlag for identifikasjon med de andre. På dette området var det mye enklere med hofteprotesene. Men vi med Huntingtons sykdom opplever alle energitap, så da blir det mindre sosialt initiativ uansett.

Jeg kjenner nå at jeg har levd et godt, langt og rikt liv, med familie og venner. Jeg har hatt en yrkeskarriere der jeg har kunnet utfolde meg, og har hatt stor arbeidskapasitet og arbeidsglede. Ikke ante jeg at jeg 68 år gammel skulle sitte og skrive om hvordan det er å ha Huntingtons sykdom. Det ble rett og slett min takstein. Jeg er bare lykkelig for at den ikke falt i hodet på meg for 20-30 år siden.

\section{Tove Berg}

toven.berg@getmail.no

\section{Litteratur \\ 1. Sontag S. Sykdom som metafor. Oslo: Gyldendal, 1979}

Mottatt 2.7. 2013 og godkjent 29.8. 2013. Redaktør Sigurd Høye. 